\title{
ON MANIRAPTORAN MATERIAL (DINOSAURIA: THEROPODA) FROM VALE DO RIO DO PEIXE FORMATION, BAURU GROUP, BRAZIL
}

\author{
RAFAEL DELCOURT \\ Laboratório de Paleontologia, Museu de Zoologia da Universidade de São Paulo, Avenida Nazaré, 481, \\ 04263-000, São Paulo, SP, Brazil.rafadsf@hotmail.com \\ ORLANDO NELSON GRILLO \\ Departamento de Geologia e Paleontologia, Museu Nacional, Universidade Federal do Rio de Janeiro, \\ 20940-040, Rio de Janeiro, RJ, Brazil.ongrillo@mn.ufrj.br
}

\begin{abstract}
Non avian theropod remains are scarce in Brazil and few specimens were referred to Maniraptora. Remains of a non-avian theropod dinosaur (DGM 930-R) from Vale do Rio do Peixe Formation, Bauru Group, found near the Santo Anastácio municipality, São Paulo State are described. DGM 930-R is represented by two partial caudal vertebra centra, a partial diaphysis of the right femur with marked lines of arrested development (indicatives of a habitat with marked seasonality), a partial dorsal rib and other rib fragments, a partial bone that possibly represents the proximal portion of the ischium, and some unidentifiable elements. DGM 930-R is referred as a Maniraptoran incertae sedis, possibly related to Deinonychosauria because of the box-like anterior vertebral centrum with quadrangular-shaped posterior articulation. The circumference of the femur of DGM 930-R suggests it was a medium-sized dinosaur (about $3 \mathrm{~m}$ long) that shared the same geographic space with other theropods (megaraptorans, abelisauroids, and carcharodontosaurids) and mesoeucrocodylians.
\end{abstract}

Key words: Theropoda, Maniraptora, Bauru Group, Brazil.

RESUMO - Terópodes não avianos são raros no Brasil e apenas alguns espécimes foram referidos a Maniraptora. No presente trabalho são descritos restos de um terópode não aviano (DGM 930-R) da Formação Vale do Rio do Peixe, Grupo Bauru, encontrados próximos ao município de Santo Anastácio, São Paulo. DGM 930-R é representado por dois centros vertebrais parciais, parte de uma diáfise do fêmur esquerdo com linhas de parada de crescimento bem delimitadas (indicativos de habitat com sazonalidade marcada), parte de costela dorsal e outros fragmentos de costelas, uma possível parte proximal do ísquio e alguns elementos não identificáveis. DGM 930-R é referido como Maniraptora incertae sedis, possivelmente relatado a Deinonychosauria, pois o centro vertebral mais anterior, com formato de caixa, apresenta a forma da articulação posterior quadrangular. A circunferência do fêmur de DGM 930-R sugere que se tratava de um dinossauro de porte médio (aproximadamente $3 \mathrm{~m}$ de comprimento) que compartilhou o mesmo espaço geográfico com outros terópodes (megaraptores, abelissauroideos e carcarodontossaurídeos) e mesoeucrocodilianos.

Palavras-chave: Theropoda, Maniraptora, Grupo Bauru, Brasil.

\section{INTRODUCTION}

For almost two centuries, non-avian theropod dinosaurs have been treated as icons by the society and by the scientific community. Although the Brazilian dinosaur fossil record is fairly good for sauropodomorphs, both theropods and ornithischian remain are poorly known. Currently, different theropod taxa have been described for some geological basins in Brazil, especially the Bauru Basin (Novas et al., 2005, 2008; Machado et al., 2008, 2013; Bittencourt \& Langer, 2011; Candeiro et al., 2012a; Martinelli et al., 2013; Méndez et al., 2012, 2014) increasing our knowledge about the dinosaurian diversity in Brazil. In the Bauru Basin of Brazil, the occurrence of Maniraptora is based upon isolated teeth
(Bertini et al., 1997; Bertini \& Franco-Rosas, 2001; FrancoRosas, 2002), a scapula (Machado et al., 2008), a manual ungual phalanx (Novas et al., 2005) and a dorsal vertebra (Candeiro et al., 2012a).

A new specimen (DGM 930-R) that was collected in 1950 in a quarry to the west of Santo Anastácio city, São Paulo State (Vale do Rio do Peixe Formation; Bauru Basin) is presented, which is referred to Maniraptora. The material is fragmentary, without signs of deformation and bone surfaces are well preserved with some visible muscle scars. DGM 930-R includes two partial vertebral centra, a partial diaphysis of the left femur, partial ungual, partial ribs, an unidentified partial bone that possibly represents the proximal portion of the ischium, and some non-diagnosable elements. 
Institutional abbreviations. DGBU, Department of Geology, Pusan (Busan) National University, Pusan, Korea; DGM, Museu de Ciências da Terra, Departamento Nacional de Produção Mineral, Rio de Janeiro, Brazil; IGM, Mongolian Institute of Geology, Ulan Baatar, Mongolia.

\section{SYSTEMATIC PALEONTOLOGY}

Superorder DINOSAURIA Owen, 1842

Suborder THEROPODA Marsh, 1881

MANIRAPTORA incertae sedis Gauthier, 1986

(Figures 2-4)

Material. DGM 930-R, fragmentary postcranial elements including two caudal vertebra centra, a partial diaphysis of the right femur, a partial ungual, a partial dorsal rib and other rib fragments, a partial bone that possibly correspond to the proximal portion of the ischium, and some unidentifiable elements.

Locality and horizon. An old quarry to the west of Santo Anastácio city, São Paulo State, Brazil; CampanianMaastrichtian Vale do Rio do Peixe Formation, Bauru Basin (Figure 1; Fernandes \& Coimbra, 2000). The Bauru Basin corresponds mainly of sandstones deposited during semi-arid to arid climate, between the Coniacian and Maastrichtian; it extends over an area of $370,000 \mathrm{~km}^{2}$ in the Brazilian states of São Paulo, Paraná, Mato Grosso do Sul, Minas Gerais and Goiás. The Vale do Rio do Peixe Formation is composed of sandstones intercalated with siltstones and sandy mudstones; the sandstones consist mainly in aeolian deposits while the

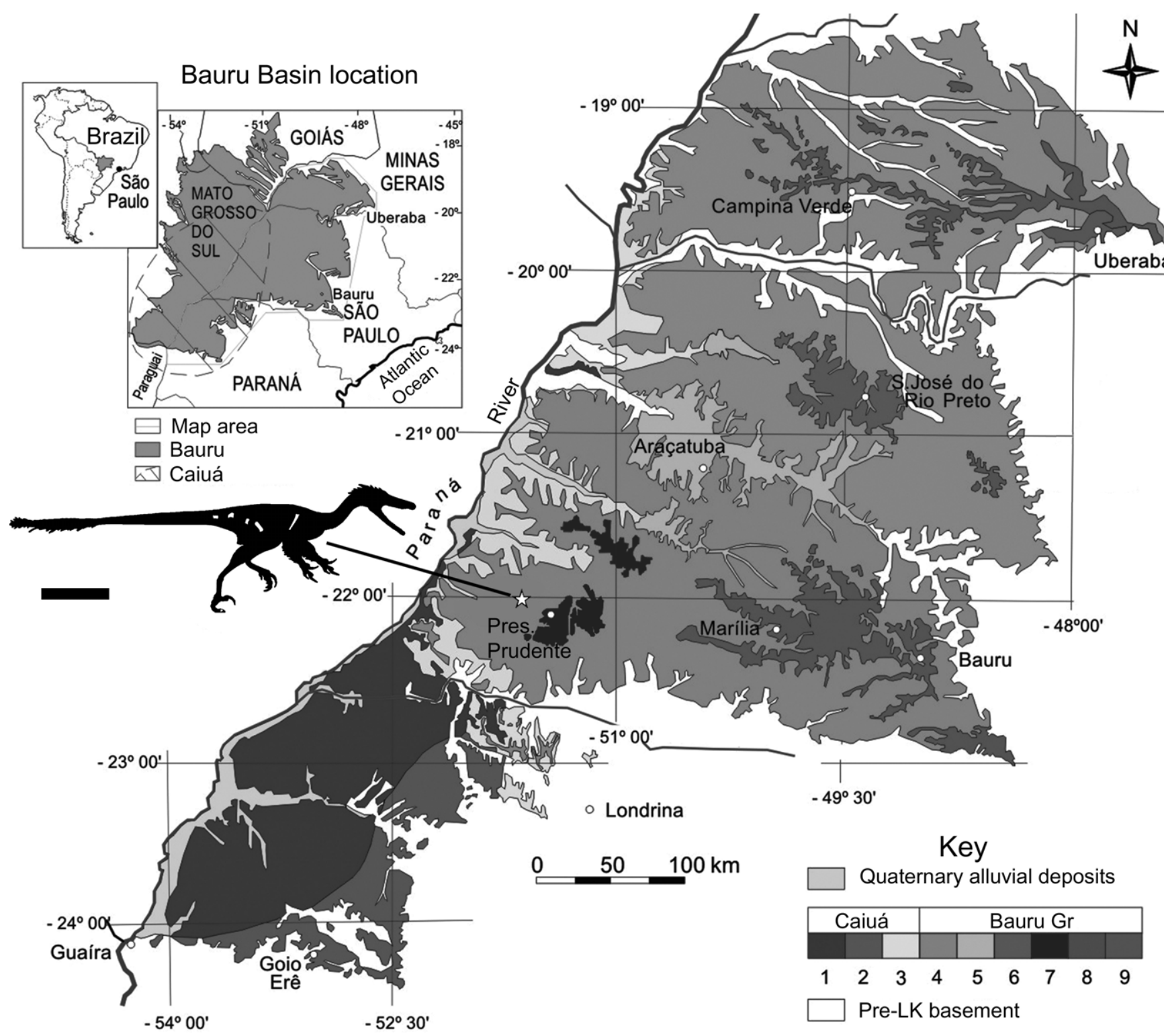

Figure 1. Geological map of the Bauru Basin showing the location of the old quarry to the west of the Santo Anastácio municipality (white star) in southwestern São Paulo State (modified from Fernandes et al., 2007). 1, Rio Paraná Formation; 2, Goio Erê Formation; 3, Santo Anastácio Formation (Caiuá Group); 4, Vale do Rio do Peixe Formation; 5, Araçatuba Formation; 6, São José do Rio Preto Formation; 7, Presidente Prudente Formation; 8, Uberaba Formation; 9, Marília Formation (Bauru Group). Silhouette modified from Porfiri et al. (2011). Scale bar =50 cm. 
mudstones were probably deposited in depressions in shallow and ephemeral aqueous bodies, created during periods of higher water level (see Fernandes \& Coimbra, 2000 for detailed review of the Bauru Basin).

Unfortunately there is no information about the exact locality where DGM 930-R was found. These materials were kept unstudied for more than 50 years without more information. Because in the Santo Anastácio municipality there are several outcrop of the Vale do Rio do Peixe Formation, we are confident that the specimen DGM 930-R comes from this unit.

Description. The largest preserved vertebral centrum (Figures 2A-E; see Table 1 for measurements). The presence of an articular surface for a chevron (Figure 2E, ch) and its format (box-like) indicate it is an anterior caudal. The vertebra is broken dorsal to the level of the neurocentral suture, and the dorsal portion of the neural arch including the transverse process is missing (Figure $2 \mathrm{C}$ ), suggesting the centrum was completely fused to the neural arch. Just the ventral portion of the transverse process and neural canal are preserved. The vertebra is amphicoelous, with the articular surfaces slightly concave and the borders thick and rounded. It has a box-like shape in anterior view; the lateral margins are flat, and the ventral margin is slightly curved (Figure 2C) and the posterior articular face is quadrangular-shaped (i.e. the posterior edge are straight and sub-parallel and the ventral edge is also straight) (Figure 2B). The borders of the anterior articulation are damaged, so it is not clear if it was also quadrangular-shaped as the posterior articular face. The ventral surface does not present any groove. The left lateral surface has a shallow depression in the anterior part, but it is not a pleurocoel, which was not present in any of the preserved vertebrae of this specimen. In both lateral surfaces there are tuberosities that were interpreted as the origin of the muscle caudofemoralis longus (sensu Romer, 1923). Beyond the tuberosities, there are also several small foramina spread on both lateral sides of the centrum and at the base of the transverse processes (Figures 2A, C).

The second preserved vertebral centrum (Figures $2 \mathrm{~F}-\mathrm{H}$ ) is cranio-caudally elongated and subcircular in posterior view (Figure 2F; see Table 1 for dimensions). The size and proportions of this centrum compared to the largest one (Table 1) suggests a posterior position in the caudal series. It has two large foramina on the right side (Figure 2G) and a large one on the left side along with other smaller foramina. Different to the more anterior caudal centrum, this one is broken at the suture of the neural arch. It is also amphicoelous and also bears muscle scars for the muscle caudofemoralis longus below the sutures. The ventral surface does not bear any groove or keel, so the centrum is spool-shaped.

The preserved part of the diaphysis of the right femur is subcircular in cross section (Figure 3; Table 1). The measured circumference (Table 1) suggests the total length of the femur was about $273 \mathrm{~mm}$ based on equations provided by Christiansen (1999). The mid-shaft of the femur is slightly curved and hollow (Figures 3E-F) and bears three distinctive muscle scars. The first one is interpreted as the adductor ridge (Figure 3C, ar), because it has the shape of an oval concavity (Hutchinson, 2001) located on the medioposterior surface of the diaphysis (Figure 3C). The surface, where this scar is located, is flatter than the surface of the more proximal part of the shaft of the femur. The second preserved scar was interpreted as the linea intermuscularis cranialis (Figure 3B), a ridge that extends from the proximal anteromedial surface to the distal medial surface of the femur (Hutchinson, 2001). The last scar possibly corresponds to the linea intermuscularis caudalis (Figure 3C). The shape and orientation of the preserved portion of these structures suggest this material correspond to the distal half of the diaphysis.

The fragment of the diaphysis of the femur also shows marked lines of arrested growth (LAGs; Figure 3G), suggesting its growth was periodically interrupted or reduced by environmental cyclical events (Chinsamy \& Rubidge,

Table 1. Measurements $(\mathrm{mm})$ of preserved elements of DGM 930-R. Symbol: * estimated values.

\begin{tabular}{|c|c|c|c|c|c|}
\hline Measurement & caudal centrum 1 & caudal centrum 2 & femur & ischium? & pedal ungual \\
\hline Length (preserved portion) & 42 & 37 & 70 & 40 & 21 \\
\hline Total length & 42 & $41^{*}$ & $273^{*}$ & $?$ & $?$ \\
\hline Width of anterior articular surface & $34 *$ & $?$ & - & - & - \\
\hline Height of anterior articular surface & 31 & $?$ & - & - & - \\
\hline Width of posterior articular surface & 36 & 27 & - & - & - \\
\hline Height of posterior articular surface & $25^{*}$ & 23 & - & - & - \\
\hline Midshaft anteroposterior diameter & - & - & 22 & - & - \\
\hline Midshaft mediolateral diameter & - & - & 27 & $\sim 22$ & - \\
\hline Midshaft circumference & - & - & 79 & - & - \\
\hline Width of proximal articulation & - & - & - & 28 & $16^{*}$ \\
\hline Height of proximal articulation & - & - & - & $?$ & $17^{*}$ \\
\hline
\end{tabular}



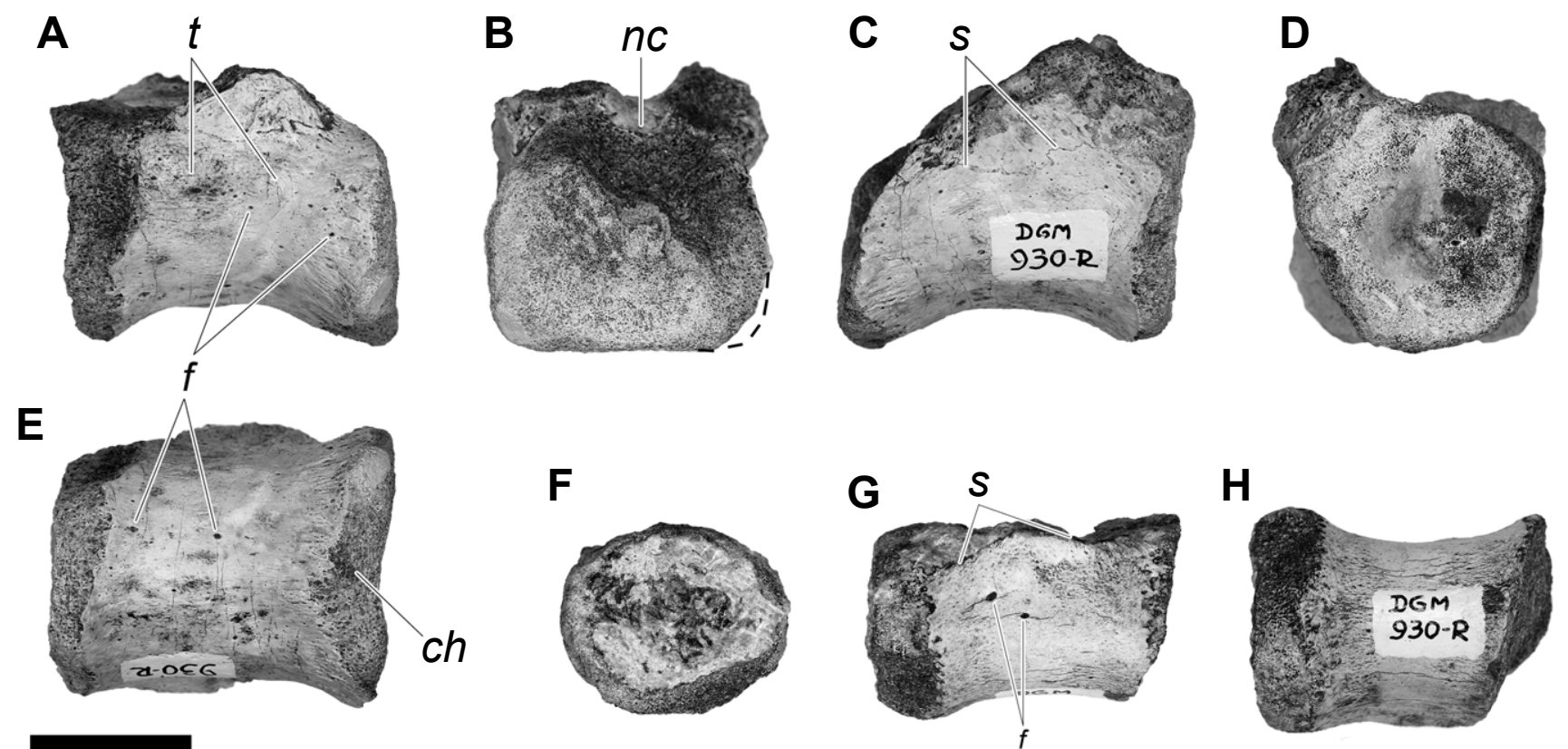

Figure 2. DGM 930-R first preserved caudal vertebra (A-E) in left lateral (A), posterior (B), right lateral (C), anterior (D), and ventral (E) views; second preserved caudal vertebra $(\mathbf{F}-\mathbf{H})$ in posterior $(\mathbf{F})$, right lateral $(\mathbf{G})$ and ventral $(\mathbf{H})$ views. Both vertebrae are broken above the suture $(\mathbf{s})$ of the transverse process, but the ventral portion of the neural canal $(\mathbf{n c})$ is preserved. Several small foramina (f) are visible as well as tuberosities (t) for the origin of muscle caudofemorales longus. In the first centrum, the region of chevron articulation (ch) is also present. Scale bar $=20 \mathrm{~mm}$.
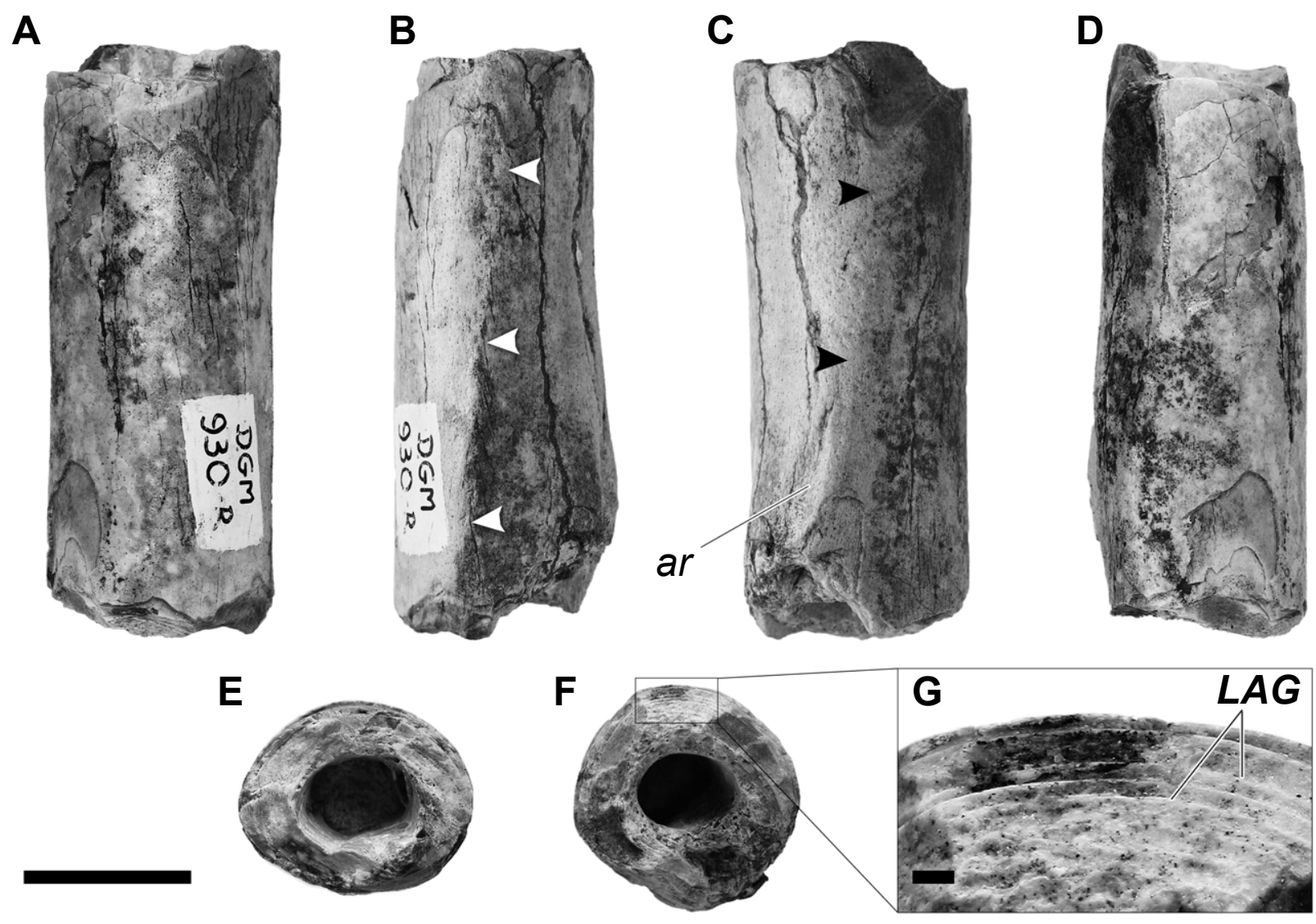

Figure 3. DGM 930-R right femur in anterior (A), medial (B), posterior (C), lateral (D), proximal (E) and distal (F) views; G, detail of the lines of arrested growth (LAG). The preserved muscle insertion scars are interpreted as the linea intermusculares cranialis (white arrowheads) and caudalis (black arrowheads) and the adductor ridge (ar). Scale bars: A-F $=20 \mathrm{~mm} ; \mathrm{G}=1 \mathrm{~mm}$. 
1993; Chinsamy et al., 1995; Padian et al., 2001), which is congruent with the proposed arid to semiarid paleoambient with occasional periods of higher water level, proposed for the Santo Anastácio Formation (Fernandes \& Coimbra, 2000). Applying the circumference of the femur in regression analyses of other dinosaurian taxa (Christiansen \& Fariña, 2004; Therrien \& Henderson, 2007; Benson et al., 2014), it was estimated a total body weight of about $34-40 \mathrm{~kg}$ and a total body length of about $3 \mathrm{~m}$ for DGM 930-R.

A fragment of bone was interpreted as the proximal portion of the ischium (Figures 4D-I) because it has a general shape that resembles the proximal ischium of Saurornithoides mongoliensis (Norell et al., 2009). It has an internal cavity, as is indicated by bone surfaces that are partially preserved (Figures 4G, I). The proximal end is highly porous and expanded with a marked flat articular surface (the preserved portion supposedly correspondent to the iliac articulation surface). In the distal end (in distal view; Figure 4I), a ventral expansion (partially broken) possibly corresponds to the most proximal portion of the obturator process. Unfortunately, the poor preservation of this bone fragment makes this diagnosis highly uncertain.

This specimen also includes a partial ungual phalanx, but only the proximal portion is preserved and yet poorly preserved (Figure 4A; Table 1). The ventral surface is flat but inclined and the dorsal surface is slightly concave. The ratio between the width of the ventral and dorsal articular surfaces suggest it is a pedal ungual, as seen in other theropod dinosaurs, such as Deinonychus antirrhopus (Ostrom, 1969, fig. 75), Raptorex kriegsteini, Aucasaurus garridoi and Santanaraptor placidus (pers. obs.). It is not possible to determine to which pedal it corresponds, but, proportions suggest it was from the toes I or IV.

Several rib fragments are preserved (Figure 4A). The biggest one is $120.5 \mathrm{~mm}$ long (proximal and distal ends are lacking). It is triangular in cross section, and has marked muscle scars. Other rib fragments are triangular to sub-circular in cross section.
A

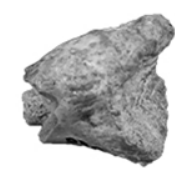

B

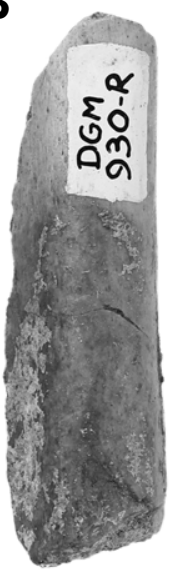

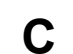

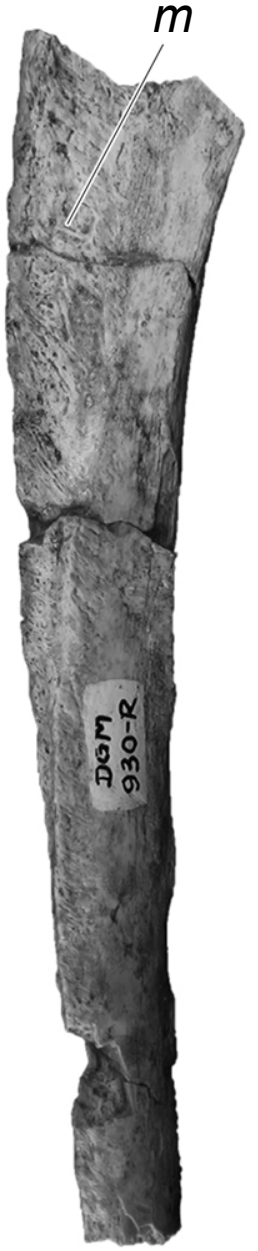

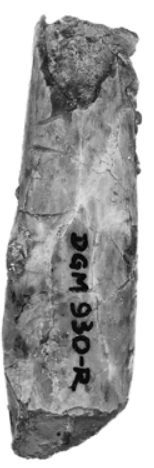
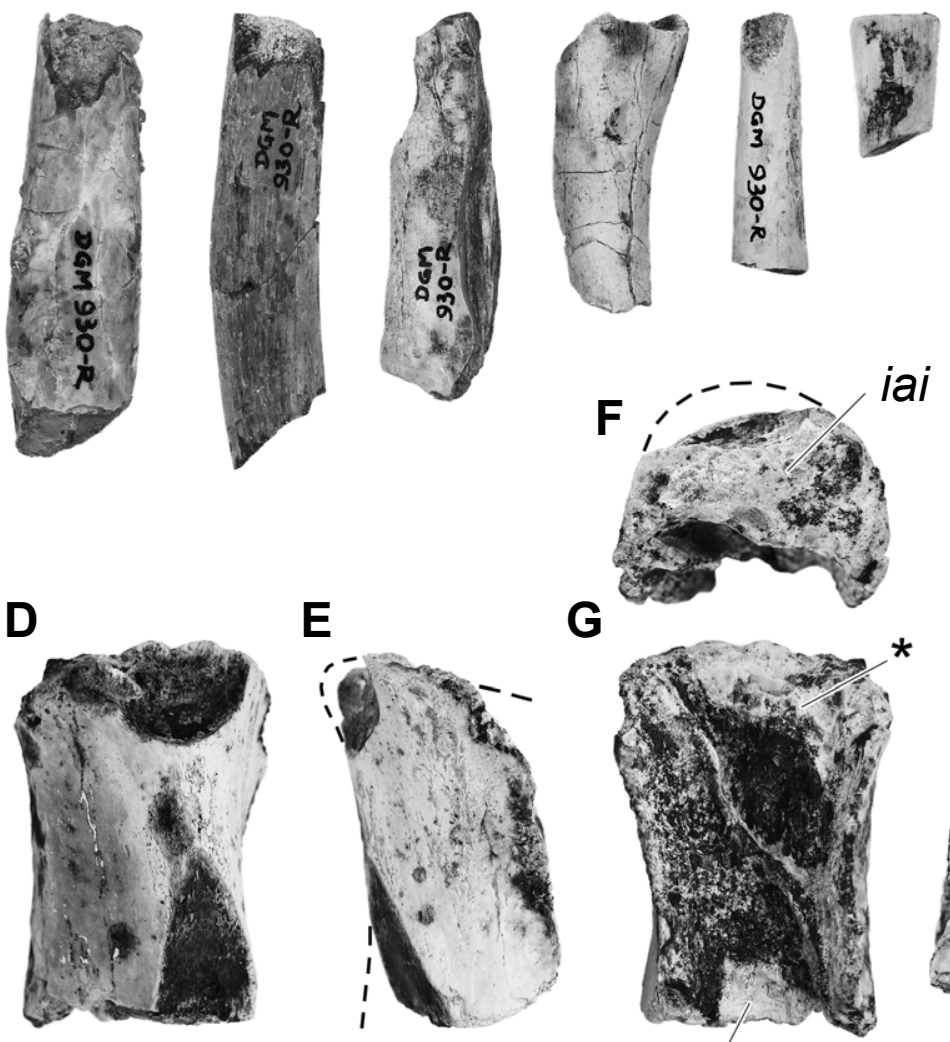

E
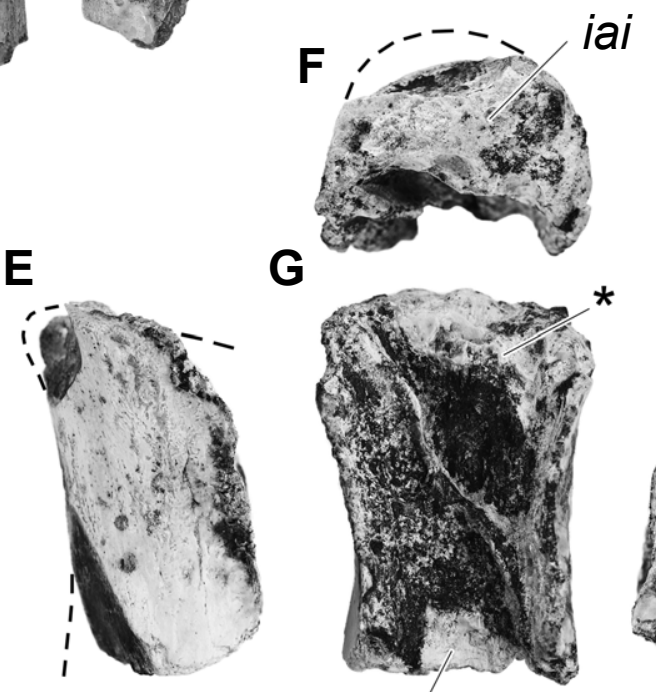

$\mathbf{G}$

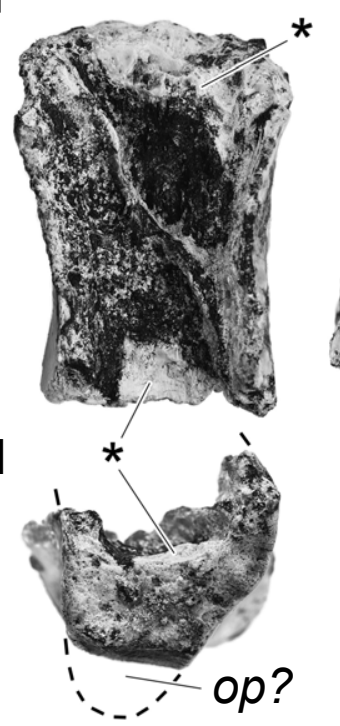

\section{H}

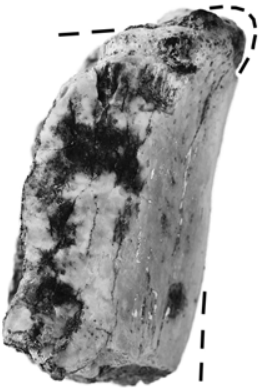

Figure 4. A-I, other preserved bones of DGM 930-R: partial pedal ungual in dorsal view (A), fragment of unidentified long bone (B), rib fragments (C) with indication of muscle scars $(\mathbf{m})$, and fragment interpreted as the proximal portion of the ischium in anterior (D), left lateral (E), proximal (F), posterior (internal), $(\mathbf{G})$, right lateral $(\mathbf{H})$, distal $(\mathbf{I})$ views. This fragment has a hollow internal cavity as internal bone surfaces are preserved $(*)$; the supposed iliac articulation of the ischium (iai), obturator process (op?), and broken parts (dashed lines) are also indicated. Scale bar $=20 \mathrm{~mm}$. 


\section{DISCUSSION}

As most of the preserved bones of DGM 930-R are fragmented, comparisons to other taxa are difficult. The two caudal vertebral centra are the most diagnostic remains, as the preserved portion of the femur is not informative. Boxlike anterior caudal vertebral centrum are characteristic of maniraptorans of the Paraves group (Turner et al., 2012), but were also present in oviraptorosaurs, such as Conchoraptor gracilis and Microvenator celer (Turner et al., 2012) and in therizinosaur Falcarius utahensis (Zanno, 2010). Consequently, DGM 930-R is classified as a maniraptoran. In this work abelisauroids are excluded, a well represented taxa in Brazilian cretaceous strata (e.g. Méndez et al., 2014), because they have spool-shaped anterior vertebrae, as seen in Masiakasaurus knopfleri (noasaurid), Carnotaurus sastrei, Aucasaurus garridoi and Pycnonemosaurus nevesi (abelisaurids). The presence of maniraptoran dinosaurs in the Southern Hemisphere has been confirmed by several authors (Novas \& Pol, 2005; Machado et al., 2008; Agnolín \& Novas, 2011; Gianechini \& Apesteguía, 2011; Benson et al., 2012; Novas et al., 2005, 2009, 2013; Turner et al., 2012). Therefore comparisons of DGM $930-\mathrm{R}$ to other taxa will be restricted to maniraptorans in which this type of caudal vertebra was observed.

Compared to caudal vertebrae of oviraptorosaurs, DGM 930-R differs in several aspects. Oviraptorosaurs have amphiplatyan caudal centra and the cranial ones are spoollike whereas the caudal ones are box-like, a condition that is opposite to the observed in DGM 930-R in which the anterior caudal is box-like. In DGM 930-R, pleurocoels and a ventral groove are absent on both preserved vertebra; oviraptorosaur vertebrae sometimes have a single pleurocoel close to the base of the neural arch (Osmólska et al., 2004), as in Heyuannia huangi (Lü, 2002) and Gigantoraptor erlianensis (Xu et al., 2007), and, except for the first proximal centrum, have a ventral wide shallow groove (Osmólska et al., 2004). Also, the distal caudal of DGM 930-R is not as short and dorsoventrally compressed as distal caudals of oviraptorosaurs, in which the mediolateral width exceeds the dorsoventral depth (Osmólska et al., 2004), and does not have ventrally located transverse process, as in Microvenator celer (Makovicky \& Sues, 1998) and Gigantoraptor erlianensis (Xu et al., 2007).

Compared to Alvarezsauridae, there are important differences in the shape of the caudal vertebrae. In most Alvarezsauridae (Achillesaurus manazzonei, Alvarezsaurus calvoi, Mononykus olecranus, Parvicursor remotus, Patagonykus puertai, Shuvuuia deserti and Xixianykus zhangi), the caudal vertebrae are procoelous (Chiappe et al., 2002; Martinelli \& Vera, 2007; Choiniere et al., 2010; $\mathrm{Xu}$ et al., 2010), but in Achillesaurus the fourth caudal is amphicoelous (Martinelli \& Vera, 2007). Anterior caudal centra of alvarezsaurids are also laterally compressed with a ventral keel in Achillesaurus, Alvarezsaurus, Mononykus, Shuvuuia and Xixianykus (Martinelli \& Vera, 2007; Choiniere et al., 2010; Xu et al., 2010), but there is no ventral keel in the anterior caudal centra of Patagonykus (Novas, 1997). DGM
930-R differs from alvarezsaurids in that the anterior caudal centrum is subrectangular, box-like and is amphicoelous. In Patagonykus the distal caudal centrum is strongly procoelous and has a ventral sulcus (Novas, 1997). A shallow longitudinal sulcus is also present in the middle caudal of Achillesaurus (Martinelli \& Vera, 2007). The more distal preserved caudal of DGM 930-R does not have a ventral sulcus, but it is not possible to define if it was amphicoelous or procelous.

The preserved portion of the femur of DGM 930-R differs from Linhenykus monodactylus because the anterior surface near the distal end is slight convex in the lateral surface and concave in medial one (Xu et al., 2013). The muscle scars in the femur of DGM 930-R are more marked than in Linhenykus. The mid-shaft of the femur of Mononykus has a subtriangular cross section with a flat caudal surface (Altangarel et al., 1994) that differs from the oval cross section of the shaft of the femur of DGM 930-R.

Among deinonychosaurian taxa, dromaeosaurids in general have short and box-shaped anterior caudal centra with a subquadrangular cross-section (Senter et al., 2012). Variably, a mediolaterally narrow and shallow ventral longitudinal groove is present, as is the case of Deinonychus antirrhopus (Ostrom, 1969), Velociraptor mongoliensis (Norell \& Makovicky, 1997, 1999), Pyroraptor olympius (Allain \& Taquet, 2000), and Buitreraptor gonzalezorum (Turner et al., 2007). However, the centra of anterior caudal vertebrae of Yurgovuchia doellingi have rounded cranial and caudal articulations and are also round in cross-section, a condition also observed in Achillobator (Senter et al., 2012). Box-shaped anterior centra are also observed in the troodontid Saurornithoides mongoliensis (Norell et al., 2009). The anterior caudal vertebrae of Deinonychus are also characterized by having a quadrangular-shaped posterior articulation and slightly platycoelous articular facets (Ostrom, 1969), while those of Yurgovuchia are amphiplatyan (Senter et al., 2012). The posterior caudal vertebrae of dromaeosaurids become longer and lower progressively on about the tenth caudal (Norell \& Makovicky, 2004). However in Buitreraptor gonzalezorum this shift starts on the third caudal centrum. In troodontids the posterior caudal vertebrae are elongated as in dromaeosaurids (Makovicky \& Norell, 2004). DGM 930-R is similar to most dromaeosaurids in that the anterior caudal is box-shaped, with the posterior articulation quadrangularshaped, but differs in that a ventral groove is absent. The centrum of the posterior caudal of DGM 930-R is also similar to Velociraptor, being subcircular in cross section (Norell \& Makovicky, 1999), but differs because the ventral groove is absent.

The mid shaft of the femur of dromaeosaurids has a nearly circular cross-section, as observed in Deinonychus (Ostrom, 1976), Velociraptor mongoliensis (Norell \& Makovicky, 1999) and Unenlagia comahuensis (pers. obs.). In Deinonychus, the ratio between anteroposterior and mediolateral diameters of the midshaft is similar to DGM 930-R. DGM 930-R differs from Buitreraptor gonzalezorum and Mahakala omnogovae in that they have a flatter distal end 
(Turner et al., 2007). The femur of DGM 930-R also differs from DGBU-78, a maniraptoran from Korea, in which the shaft of the femur is anteroposteriorly compressed (Kim et al., 2005). The femur of Neuquenraptor argentinus is more robust than that of Unenlagia comahuensis (Novas \& Pol, 2005) and DGM 930-R.

One of the bone fragments of DGM 930-R was identified as the proximal portion of the ischium (Figures 4D-I) because it has a morphology that is quite similar to the figured by Norell et al. (2009) for the troodontid Saurornithoides mongoliensis. Unfortunately, the fragmentary nature of this fragment of bone does not allow to confirm that it in fact correspond to the ischium; also, it is not possible to make detailed comparisons to other taxa.

Most of the diagnostic characteristics of DGM 930-R allow to exclude it from Oviraptorosauria and to classify it as a non-Alvarezsauridae maniraptoran dinosaur. Unfortunately, the preserved material does not allow further studies to resolve its phylogenetic position. It is similar to Deinonychosauria in several aspects, but it cannot be undoubtedly attributed to this group because of the lack of a ventral groove on the caudal vertebrae. Consequently, we refer DGM 930-R to the Maniraptora group, tentatively referred to Deinonychosauria. In South America, Deinonychosauria is well represented by the Unenlagiinae (Agnolín \& Novas, 2011; Gianechini \& Apesteguía, 2011; Candeiro et al., 2012a; Novas et al., 2013), but the presence of Deinonychosauria was also claimed in Brazil based upon isolated teeth (Vilas Bôas et al., 1999; Bertini et al., 1997; Bertini \& Franco-Rosas, 2001; FrancoRosas, 2001, 2002; Elias et al., 2007) and a dorsal vertebra (Candeiro et al., 2012a). Therefore, if DGM 930-R is actually a maniraptoran theropod, it adds more information on this clade in the Late Cretaceous of Brazil.

According to some authors (Candeiro et al., 2006; Martinelli \& Pais, 2008; Riff \& Kellner, 2011) the top cretaceous predators of the Bauru fauna were the baurusuchid crocodilians. However, the presence of DGM 930-R in the Bauru besides megaraptoran (Méndez et al., 2012; Martinelli et al., 2013;), abelisauroid (Kellner \& Campos, 2002; Novas et al., 2008; Candeiro et al., 2012b; Machado et al., 2013; Méndez et al., 2014) and carcharodontosaurid theropods ( Candeiro et al., 2012b; Azevedo et al., 2013) indicates the cretaceous fauna of the Bauru also included small/medium sized predatory dinosaurs. We can hypothesize that these theropod taxa occupied a predatory niche as important as the baurusuchids, however this question may be explored with more caution. Despite the fragmentation and incomplete nature of the theropod material from the Bauru Basin, the surfaces of these bones are well preserved. This is particularly enigmatic because in comparison, most mesoeucrocodylian fossils from the Bauru Basin are represented by virtually complete skeletons (Nascimento \& Zaher, 2010; Riff \& Kellner, 2011). Taphonomic and additional field works are necessary to answer this question.

The material described here contribute to increase the number of occurrences of Maniraptora, especially in Brazil, where most materials are incomplete (Novas et al., 2005;
Elias et al., 2007; Machado et al., 2008; Bittencourt \& Langer, 2011; Candeiro et al., 2012a). It also contributes for the knowledge of morphological variations among these theropods, considering that DGM 930-R has caudal vertebrae without a ventral groove, a condition that differs from others taxa.

\section{CONCLUSIONS}

DGM 930-R increases the knowledge about the fauna of the Bauru Basin during the Late Cretaceous. Although it is not possible to define to which taxonomic family this specimen belong, some characters allow to infer that DGM 930-R was a medium-size maniraptoran, possibly closely related to Deinonychosauria. Its presence indicates that important predators other than baurusuchids, megaraptorans, abelisauroids and carcharodontosaurids may inhabited this region during the Cretaceous, thus contributing for the record of theropod diversity in the Bauru Group.

\section{ACKNOWLEDGEMENTS}

The authors thank to D.A. Campos and R. Machado (Departamento Nacional de Produção Mineral, Rio de Janeiro, Brazil) for allowing the access to the Paleontological Collection of the DNPM and for the loan of DGM 930R. Thanks to L.A. Fernandes (Universidade Federal do Paraná, Curitiba, Brazil) for providing the map of the Bauru Basin. Thanks to R.A. Coria (Museo Carmen Funes, Plaza Huincul, Argentina), L.B. Carvalho (Museu Nacional/ UFRJ, Rio de Janeiro, Brazil), and to the two reviewers, A. Martinelli (Universidade Federal do Rio Grande do Sul, Porto Alegre, Brazil) and J. Choiniere (University of the Witwatersrand, Johannesburg, South Africa), for providing important comments on the manuscript; to F.L. Agnolín (Museo Argentino de Ciencias Naturales "Bernardino Rivadavia", Buenos Aires, Argentina) for providing pictures of Alvarezsaurus and Patagonykus for comparison; to W.A. Pinto (Museu de Zoologia da Universidade de São Paulo, São Paulo, Brazil) for reviewing the English language.

\section{REFERENCES}

Agnolín, F.L. \& Novas, F.E. 2011. Unenlagiid theropods: are they members of the Dromaeosauridae (Theropoda, Maniraptora)? Anais da Academia Brasileira de Ciências, 83:117-162. doi:10.1590/s0001-37652011000100008

Allain, R. \& Taquet, P. 2000. A new genus of dromaeosauridae (Dinosauria, Theropoda) from the Upper Cretaceous of France. Journal of Vertebrate Paleontology, 20:404-407. doi:10.1671/0272-4634(2000)020[0404:ANGODD]2.0.CO;2

Altangarel, P.; Chiappe, L.M.; Rinchen, B.; Clark, J.M. \& Norell, M.A. 1994. Skeletal morphology of Mononykus olecranos (Theropoda: Avialae) from the Late Cretaceous of Mongolia. American Museum Novitates, 3105:1-29.

Azevedo, R.P.F.; Simbras, F.M.; Furtado, M.R.; Candeiro, C.R.A. \& Bergqvist, L.P. 2013. First Brazilian carcharodontosaurid and other new theropod dinosaur fossil from the Campanian- 
Maastrichtian Presidente Prudente Formation, São Paulo State, southeastern Brazil. Cretaceous Research, 40:131-142. doi:10.1016/j.cretres.2012.06.004

Benson, R.B.; Campione, N.E.; Carrano, M.T.; Mannion, P.D.; Sullivan, C.; Upchurch, P. \& Evans, D.C. 2014. Rates of dinosaur body mass evolution indicate 170 million years of sustained ecological innovation on the avian stem lineage. PLoS Biology, 12:1-11. doi:10.1371/journal.pbio.1001853

Benson, R.B.; Rich, T.H.; Vickers-Rich, P. \& Hall, M. 2012. Theropod fauna from southern Australia indicates high polar diversity and climate-driven dinosaur provinciality. PloS One, 7:1-29. doi:10.1371/journal.pone.0037122

Bertini, R.J. \& Franco-Rosas, A.C. 2001. Scanning eletronic miscroscopic analysis on Maniraptoriformes teeth from the Upper Cretaceous of southeastern Brazil. Journal of Vertebrate Paleontology, 21:33A.

Bertini, R.J.; Franco, A.C.; Toledo, C.E.V. \& Campos, A.C.A. 1997. Theropod teeth from the Adamantina Formation, Upper Cretaceous of São Paulo State. Analysis of dental morphology. In: CONGRESSO BRASILEIRO DE PALEONTOLOGIA, 15 1997. Boletim de Resumos, São Pedro, SBP, p. 103.

Bittencourt, J.S. \& Langer, M.C. 2011. Mesozoic dinosaurs from Brazil and their biogeographic implications. Anais da Academia Brasileira de Ciências, 83:23-60. doi:10.1590/s000137652011000100003

Candeiro, C.R.A.; Cau, A.; Fanti, F.; Nava, W. \& Novas, F.E. 2012a. First evidence of an unenlagiid (Dinosauria, Theropoda, Maniraptora) from the Bauru Group, Brazil. Cretaceous Research, 37:223-226. doi:10.1016/j.cretres.2012.04.001

Candeiro, C.R.A.; Currie, P.J. \& Bergqvist, L.P. 2012b. Theropod teeth from Marília Formation (late Maastrichtian) at the Paleontological Site of Peirópolis in Minas Gerais State, Brazil. Revista Brasileira de Geociências, 42:323-330. doi:10.5327/ Z0375-75362012000200008

Candeiro, C.R.A.; Martinelli, A.G.; Avila, L.S. \& Rich, T. 2006. Tetrapods from the Upper Cretaceous (Turonian/Maastrichtian) Bauru Group of Brazil: a reappraisal. Cretaceous Research, 27:923-946. doi:10.1016/j.cretres.2006.05.002

Chiappe, L.M.; Norell, M.A. \& Clark, J.M. 2002. The Cretaceous, short-armed Alvarezsauridae: Mononykus and its kin. In: L.M. Chiappe \& L.M. Witmer (eds.) Mesozoic Birds: Above the Heads of Dinosaurs, University of California Press, p. 87-120.

Chinsamy, A.; Chiappe, L.M. \& Dodson, P. 1995. Mesozoic avian bone microstructure: physiological implications. Paleobiology, 21:561-574.

Chinsamy, A. \& Rubidge, B.S. 1993. Dicynodont (Therapsida) bone histology: phylogenetic and physiological implications. Palaeontologia Africana, 30:97-102.

Choiniere, J.N.; Xu, X.; Clark, J.M.; Foster, C.A.; Guo, Y. \& Han, F. 2010. A basal alvarezsauroid theropod from the Early Late Jurassic of Xinjiang, China. Science, 327:571-574. doi:10.1126/ science. 1182143

Christiansen, P. 1999. Long bone scaling and limb posture in nonavian theropods: evidence for differential allometry. Journal of Vertebrate Paleontology, 19:666-680. doi:10.1080/02724634. 1999.10011180

Christiansen, P. \& Fariña, R.A. 2004. Mass prediction in theropod dinosaurs. Historical Biology, 16:85-92. doi:10.1080/0891296 0412331284313
Elias, F.A.; Bertini, J.R. \& Medeiros, M.A.A. 2007. Velociraptorinae (Maniraptoriformes) teeth from the Coringa Flagstone outcrop, Middle Cretaceous of the São Luís-Grajaú Basin, Maranhão State, northern-northeastern Brazil. In: I.S. Carvalho; R.C.T. Cassab; C. Schwanke; M.A. Carvalho; A.C.S. Fernandes; M.A.C. Rodrigues; M.S.S. Carvalho; M. Arai \& M. Oliveira (eds.) Paleontologia: Cenários da Vida, Interciência, vol. 1, p. 315-325.

Fernandes, L.A.; Castro, A.B. \& Basilici, G. 2007. Seismites in continental sand sea deposits of the Late Cretaceous Caiuá Desert, Bauru Basin, Brazil. Sedimentary Geology, 199:51-64. doi:10.1016/j.sedgeo.2005.12.030

Fernandes, L.A. \& Coimbra, A.M. 2000. Revisão estratigráfica da parte oriental da Bacia Bauru (Neocretáceo). Revista Brasileira de Geociencias, 30:717-728.

Franco-Rosas, A.C. 2001. Dentes de teropodomorfos da Formação Cambabe, Mato Grosso. In: CONGRESSO BRASILEIRO DE PALEONTOLOGIA, 17, 2001. Boletim de Resumos, Rio Branco, SBP, p. 157.

Franco-Rosas, A.C. 2002. Methodological parameters for identification and taxonomic classification of isolated theropodomorph teeth. Anais da Academia Brasileiras de Ciências, 74:367. doi:10.1590/S0001-37652002000200022

Gauthier, J.A. 1986. Saurischian monophyly and the origin of birds. In: K. Padian (ed.) The Origin of Birds and the Evolution of Flight, San Francisco, California Academy of Sciences, 55 p. (Memoirs 8)

Gianechini, F.A. \& Apesteguía, S. 2011. Unenlagiinae revisted: dromaeosaurid theropods from South America. Anais da Academia Brasileira de Ciências, 83:163-195. doi:10.1590/ s0001-37652011000100009

Hutchinson, J.R. 2001. The evolution of femoral osteology and soft tissues on the line to extant birds (Neornithes). Zoological Journal of the Linnean Society, 131:169-197. doi:10.1111/j.1096-3642.2001.tb01314.x

Kellner, A.W.A. \& Campos, D.A. 2002. On a theropod dinosaur (Abelisauria) from the continental Cretaceous of Brazil. Arquivos do Museu Nacional, 60:163-170.

Kim, H.M.; Gishlick, A.D. \& Tsuihiji, T. 2005. The first non-avian maniraptoran skeletal remains from the Lower Cretaceous of Korea. Cretaceous Research, 26:299-306. doi:10.1016/j. cretres.2005.01.001

Lü, J. 2002. A new oviraptorosaurid (Theropoda: Oviraptorosauria) from the Late Cretaceous of Southern China. Journal of Vertebrate Paleontology, 22:871-875. doi:10.1671/02724634(2002)022[0871:ANOTOF]2.0.CO;2

Machado, E.B.; Campos, D.A.; Calvo, J.O. \& Kellner, A.W.A. 2013. A new Abelisauroid from the Upper Cretaceous of Brazil. Revista Mexicana de Ciencias Geológicas, 30:446-452.

Machado, E.B.; Campos, D.A. \& Kellner, A.W.A. 2008. On a Theropoda scapula (Upper Cretaceous) from the Marília Formation, Bauru Group, Brazil. Paläontologische Zeitischrift, 82:308-313. doi:10.1007/BF02988897

Makovicky, P.J. \& Norell, M.A. 2004. Troodontidae. In: D.B. Weishampel; P. Dodson \& H. Osmólska (eds.) The Dinosauria, California Press, p. 184-195.

Makovicky, P.J. \& Sues, H.D. 1998. Anatomy and phylogenetic relationships of the theropod dinosaur Microvenator celer from the Lower Cretaceous of Montana. American Museum Novitates, 3240:1-27. 
Martinelli, A.G. \& Pais, D.F. 2008. A new baurusuchid crocodyliform (Archosauria) from the Late Cretaceous of Patagonia (Argentina). Systemetic Palaeontology, 7:371-381.doi:10.1016/j. crpv.2008.05.002

Martinelli, A.G; Ribeiro, L.C.B.; Neto, F.M.; Méndez, A.H.; Cavellani, C.L.; Felix, E.; Ferraz, M.L.F. \& Teixeira, V.P.A. 2013. Insight on the theropod fauna from the Uberaba Formation (Bauru Group), Minas Gerais State: new megaraptoran specimen from the Late Cretaceous of Brazil. Rivista Italiana di Paleontologia e Stratigrafia, 119:205-214.

Martinelli, A.G. \& Vera, E.I. 2007. Achillesaurus manazzonei, a new alvarezsaurid theropod (Dinosauria) from the Late Cretaceous Bajo de la Carpa Formation, Río Negro Province, Argentina. Zootaxa, 1582:1-17.

Méndez, A.H.; Novas, F.E. \& Iori, F.V. 2012. First record of Megaraptora (Theropoda, Neovenatoridae) from Brazil. Comptes Rendus Palevol, 11:251-256. doi:10.1016/j.crpv.2011.12.007

Méndez, A.H.; Novas, F.E. \& Iori, F.V. 2014. New record of abelisauroid theropods from the Bauru Group (Upper Cretaceous), São Paulo State, Brazil. Revista Brasileira de Paleontologia, 17:23-32. doi:10.4072/rbp.2014.1.03

Nascimento P.M. \& Zaher H. 2010. A new species of Baurusuchus (Crocodyliformes, Mesoeucrocodylia) from the Upper Cretaceous of Brazil, with the first complete postcranial skeleton described for the family Baurusuchidae. Papéis Avulsos de Zoologia, 50:323-361. doi:10.1590/s003110492010002100001

Norell, M.A. \& Makovicky, P.J. 1997. Important features of the dromaeosaurid skeleton: information from a new specimen. American Museum Novitates, 3215:1-28.

Norell, M.A. \& Makovicky, P.J. 1999. Important features of the dromaeosaurid skeleton II: information from newly collected specimens of Velociraptor mongoliensis. American Museum Novitates, 3282:1-45.

Norell, M.A. \& Makovicky, P.J. 2004. Dromaeosauridae. In: D.B. Weishampel; P. Dodson \& H. Osmólska (eds.) The Dinosauria, California Press, p. 196-209.

Norell, M.A.; Makovicky, P.J.; Bever, G.S.; Balanoff, A.M.; Clark, J.M.; Barsbold, R. \& Rowe, T. 2009. A review of the Mongolian cretaceous dinosaur Saurornithoides (Troodontidae: Theropoda). American Museum Novitates, 3654:1-63. doi:10.1206/648.1

Novas, F.E. 1997. Anatomy of Patagonykus puertai (Theropoda, Avialae, Alvarezsauridae), from the Late Cretaceous of Patagonia. Journal of Vertebrate Paleontology, 17:137-166. doi:10.1080/02724634.1997.10010959

Novas, F.E.; Agnolín, F.L.; Ezcurra, M.D.; Porfiri, J, \& Canale, J.I. 2013. Evolution of the carnivorous dinosaurs during the Cretaceous: The evidence from Patagonia. Cretaceous Research, 45:174-215. doi:10.1016/j.cretres.2013.04.001

Novas, F.E.; Borges Ribeiro, L.C. \& Carvalho, I.S. 2005. Maniraptoran theropod ungual from the Marilia Formation (Upper Cretaceous), Brazil. Revista do Museo Argentino de Ciencias Naturales, 7:31-35.

Novas, F.E.; Carvalho, I.S.; Ribeiro, L.C.B. \& Méndez, A.H. 2008. First abelisaurid bone remains from the Maastrichtian Marília Formation, Bauru Basin, Brazil. Cretaceous Research, 29:625635. doi:10.1016/j.cretres.2008.01.010
Novas, F.E. \& Pol, D. 2005. New evidence on deinonychosaurian dinosaurs from the Late Cretaceous of Patagonia. Nature, 433:858-861. doi:10.1038/nature03285

Novas, F.E.; Pol, D.; Canale, J.I.; Porfiri, J.D. \& Calvo, J.O. 2009. A bizarre Cretaceous theropod dinosaur from Patagonia and the evolution of Gondwanan dromaeosaurids. Proceedings of the Royal Society B, 276:1101-1107. doi:10.1098/rspb.2008.1554

Osmólska, H.; Currie, P.J. \& Barsbold, R. 2004. Oviraptosauria. In: D.B. Weishampel; P. Dodson \& H. Osmólska (eds.) The Dinosauria, California Press, p. 165-183.

Ostrom, J.M. 1969. Osteology of Deinonychus antirrhopus, an unusual theropod from the Lower Cretaceous of Montana. Peabody Museum of Natural History Yale University Bulletin, 30:1-165.

Ostrom, J.M. 1976. On a new specimen of the lower Cretaceous theropod dinosaur Deinonychus antirrhopus. Breviora, 439:1-21.

Owen, R. 1842. Report on British Fossil Reptiles. Part II. Reports of the British Association for the Advancement of Science, 11:60-204.

Padian, K.; de Ricqlès, A.J. \& Horner, J.R. 2001. Dinosaurian growth rates and bird origins. Nature, 412:405-408. doi: $10.1038 / 35086500$

Porfiri, J.D; Calvo, J.O. \& Santos, D. 2011. A new small deinonychosaur (Dinosauria: Theropoda) from the Late Cretaceous of Patagônia, Argentina. Anais da Academia Brasileira de Ciências, 83:109-116. doi:10.1590/S000137652011000100007

Riff, D. \& Kellner, A.W.A. 2011. Baurusuchid crocodyliforms as theropod mimics: clues from the skull and appendicular morphology of Stratiosuchus maxhechti (Upper Cretaceous of Brazil). Zoological Journal of the Linnean Society, 163:37-56. doi:10.1111/j.1096-3642.2011.00713.x

Romer, A.S. 1923. Crocodilian pelvic muscles and their avian and reptilian homologues. Bulletin of the American Museum of Natural History, 48: 533-552.

Senter, P.; Kirkland, J.I.; DeBlieux, D.D.; Madsen, S. \& Toth, N. 2012. New dromaeosaurids (Dinosauria: Theropoda) from the Lower Cretaceous of Utah, and the evolution of the dromaeosaurid tail. PloS One, 7:e36790. doi:10.1371/journal. pone. 0036790

Therrien, F. \& Henderson, D.M. 2007. My theropod is bigger than yours... or not: estimating body size from skull length in theropods. Journal of Vertebrate Paleontology, 27:108-115. doi:10.1671/0272-4634(2007)27[108:mtibty]2.0.co;2

Turner, A.H.; Makovicky, P.J. \& Norell, M.A. 2012. A review of dromaeosaurid systematic and paravian phylogeny. Bulletin of the American Museum of Natural History, 371:1-206. doi:10.1206/748.1

Turner, A.H.; Pol, D.; Clarke; J.A.; Erickson, G.M. \& Norell, M.A. 2007. A basal dromaeosaurid and size evolution preceding avian flight. Science, 317:1378-1381. doi:10.1126/science. 1144066

Vilas Bôas, I.; Carvalho, I.S.; Medeiros, M.A. \& Pontes, H. 1999. Dentes de Carcharodontosaurus (Dinosauria, Tyrannosauridae) do Cenomaniano, Bacia de São Luís (norte do Brasil). Anais da Academia Brasileira de Ciências, 71:846-847.

Xu, X.; Tan, Q.; Wang, J.; Zhao, X. \& Tan, L. 2007. A gigantic bird-like dinosaur from the Late Cretaceous of China. Nature, 447:844-847. doi:10.1038/nature05849

Xu, X.; Upchurch, P.; Ma, Q.; Pittman, M.; Choiniere, J.; Sullivan, C.; Hone, D.W.E.; Tan, Q.; Tan, L.; Xiao, D. \& Han, F. 2013. Osteology of the Late Cretaceous alvarezsauroid Linhenykus 
monodactylus from China and comments on alvarezsauroid biogeography. Acta Palaeontologica Polonica, 58:25-46. doi:10.4202/app.2011.0083

Xu, X.; Wang, D.Y.; Sullivan, C.; Hone, D.W.E.; Han, F.L.; Yan, R.H. \& Du, F.M. 2010. A basal parvicursorine (Theropoda: Alvarezsauridae) from the Upper Cretaceous of China. Zootaxa, 2413:1-19.
Zanno, L.E. 2010. Osteology of Falcarius utahensis (Dinosauria: Theropoda): characterizing the anatomy of basal therizinosaurs. Zoological Journal of the Linnean Society, 158:196-230. doi:10.1111/j.1096-3642.2009.00464.x

Received in June, 2014; accepted in October, 2014. 